\title{
Assessment of anxiety and depression levels of pregnant women with hyperemesis gravidarum in a case-control study
}

\author{
Hiperemezis gravidarum'lu gebelerde anksiyete ve depresyon siklığının bir olgu- \\ kontrol çalışmasi ile değerlendirilmesi
}

\author{
Yavuz Şimşek ${ }^{1}$, Önder Çelik ${ }^{1}$, Ercan Yılmaz ${ }^{1}$, Abdullah Karaer ${ }^{1}$, Engin Yıldırım ${ }^{1}$, Saim Yoloğlu ${ }^{2}$ \\ 'Department of Obstetrics and Gynecology, Faculty of Medicine, Inönü University, Malatya, Turkey \\ ${ }^{2}$ Department of Biostatistics, Faculty of Medicine, İnönü University, Malatya, Turkey
}

\section{Abstract}

\begin{abstract}
Objective: The aim of this study was to determine the depression and anxiety levels of pregnant women with hyperemesis gravidarum by using the Beck depression and anxiety inventory scoring system in a Turkish population.
\end{abstract}

Material and Methods: To ascertain this relationship, a case-control study was conducted involving 86 pregnant women in their first trimester of pregnancy. Forty-one subjects had hyperemesis gravidarum, and 45 were healthy pregnant women who served as control subjects. The groups were adjusted for age, parity, and body mass index. All included women were subjected to baseline laboratory investigations including serum TSH and total hCG levels.

Results: There were no statistically significant differences between the groups with respect to the demographic and obstetric parameters and baseline laboratory investigations except the mean serum potassium level, which was significantly lower in patients with hyperemesis gravidarum than in the control group $(p=0.039)$. Patients with hyperemesis gravidarum had significantly higher depression and anxiety scores than control cases ( $\mathrm{p}=0.0001$ and $\mathrm{p}=0.049$, respectively).

Conclusion: Our results suggest that increased anxiety and depression levels may be involved in the pathogenesis of hyperemesis gravidarum and extra psychological support may be necessary during the treatment and follow-up of these patients.

(J Turkish-German Gynecol Assoc 2012; 13: 32-6)

Key words: Hyperemesis gravidarum, depression, anxiety, pregnancy, psychological tests

Received: 1 August, 2011

Accepted: 20 November, 2011
Özet

Amaç: Bu yazıda Beck anksiyete ve depresyon skorlama sistemi kullanılarak hiperemezisli gebelerde anksiyete ve depresyon düzeylerinin araştırılması amaçlandı.

Gereç ve Yöntemler: Çalışma için 1. trimesterdeki 86 gebeyi içeren bir olgu-kontrol çalışması yapıldı. Hiperemezis gravidarumlu 41 hasta ve sağlıklı kontrol grubu olarak 45 gebe dahil edildi. Gruplar yaş, parite ve vücut kitle indeksi değerleri açısından eşleştirildi. Tüm hastalardan serum TSH ve hCG düzeylerini de içeren bazal laboratuvar tetkikleri istendi.

Bulgular: Gruplar arasında serum potasyum düzeyinin hiperemezisli olgularda anlamlı olarak düşük olması $(\mathrm{p}=0.039)$ dışında demografik, obstetrik ve laboratuvar değerleri açısından farklılık yoktu. Hiperemezisli hastaların depresyon ve anksiyete skorlanı kontrol grubuna göre anlamlı olarak daha yüksekti (Sırasıyla $p=0.0001$ ve $p=0.049$ ).

Sonuç: Artmış anksiyete ve depresyon düzeyleri hiperemezis gravidarumun patogenezinde rol oynayabilir. Bu hastaların takip ve tedavilerinde ekstra psikolojik destek gerekebilir.

(J Turkish-German Gynecol Assoc 2012; 13: 32-6)

Anahtar kelimeler: Hiperemezis gravidarum, depresyon, anksiyete, gebelik, psikolojik testler

Geliş Tarihi: 01 Ağustos 2011

Kabul Tarihi: 20 Kasım 2011

\section{Introduction}

Hyperemesis gravidarum (HG), a severe form of morning sickness, is one of the most common pregnancy-related complications. Considerable variations in the occurrence of $\mathrm{HG}$, both between and within countries, have been reported. According to Eliakim, the prevalence of $\mathrm{HG}$ varies between $0.3 \%$ and $2 \%$ (1). HG is characterized by dehydration, electrolyte imbalance, nutritional depletion and the loss of at least $5 \%$ of body weight. HG is considered to be one of the most important pregnancy-related complications that begins in the first trimester and can last throughout pregnancy, although the symptoms usually resolve by week 20 (2). The condition generally requires frequent visits to the emergency room and sometimes repeated hospitalization for intravenous hydration.

Recently published studies have found that the point prevalence of depression ranges from $8.5 \%$ to $39.0 \%$ at different times during pregnancy and from $6.5 \%$ to $12.9 \%$ at different times during the first year postpartum, which are both

Address for Correspondence: Yavuz Şimşek, Department of Obstetrics and Gynecology, Faculty of Medicine, Inönü University, Malatya, Turkey

Phone: +90 5327119911 e.mail: dryavuzsimsek@yahoo.co.uk

(c) Copyright 2012 by the Turkish-German Gynecological Education and Research Foundation - Available online at www.jtgga.org doi:10.5152/jtgga.2012.01 
slightly higher than the depression frequency in non-pregnant women (3-5).

HG is currently conceptualized as a biological illness with an unknown pathophysiological cause. Theories have suggested the influence of human chorionic gonadotropin, the pituitary axis, transient adrenal hyperthyroidism and psychogenic factors (6-8). It is well known that women of childbearing age are at an increased risk for depression and anxiety (9) and that pregnancy may increase the risk of depressive episodes (10). However, there is no data in the current literature to support the possibility that $\mathrm{HG}$ is a psychologically mediated process.

On the basis of this background, the present study used the Beck inventory to determine a possible relationship between the HG and increased level of depression and anxiety in these women.

\section{Material and Methods}

A case-control study was conducted involving 86 pregnant women in their first trimester of pregnancy. The women were selected from the outpatient obstetrics clinic of our Department of Obstetrics and Gynaecology between September 2010 and April 2011. The patients were divided into two groups. The first group included patients with a diagnosis of HG (study group) and the second group was composed of healthy pregnant women who served as controls. The groups were adjusted for age, parity, and BMI.

All participants were informed about the study and agreed to participate in the research. The study protocol was approved by the local ethics committee of the institution. The study was conducted in accordance with the basic principles of the Declaration of Helsinki.

\section{Patient selection}

The inclusion criteria for study group were as follows: (1) diagnosis of HG in a singleton pregnancy documented by the presence of severe vomiting (more than 3 times per day without any other obvious cause), an inability to maintain oral nutrition, weight loss of more than 3 kilograms and at least one positive ketonuria test $(1,2)$; (2) ability to speak Turkish and no physical or psychological disabilities that would prevent participating in the interventions; (3) no evidence of antenatal bleeding; (4) no pre-existing medical or psychiatric comorbid condition; (5) no antibiotic treatment, $\mathrm{H} 2$ blockers or proton pump inhibitors in the preceding month.

A comprehensive medical history was obtained from all pregnants, including a history of medical disorders (e.g., peptic ulcer) and chronic medication intake (e.g., non-steroidal antiinflammatory drugs) and exclusion of hyperthyroidism, psychological disorders, hepatic disorders, urinary tract infections or intracranial disorders.

An ultrasound scan was performed for all cases, including foetal biometry, placental site, amount of amniotic fluid and exclusion of any relevant obstetric condition (e.g., twin pregnancy, molar pregnancy or missed abortion).

In all patients, blood samples were taken for biochemical tests and hemogram during admission. Urine analysis for ketones was carried out for the detection of starvation ketosis.
Pregnant patients with HG were given a standard initial treatment of intravenous fluids with saline (with the addition of potassium chloride as required if patient was hypokalemic), oral thiamine (10 mg daily) and an intravenous antiemetic.

\section{Data collection}

Data were collected at the time of admission using a series of forms completed during face-to-face interviews by trained interviewers to determine the psychological status of the patients. After obtaining written informed consent, one of the co-authors (who was blinded to the study groups) carried out the interviews. The first form consisted of questions regarding the demographic characteristics of the patients. The second form included the Turkish versions of the Beck Depression Inventory (BDI) and Beck Anxiety Inventory (BAI). The BDI and BAI are 21-item self-report instruments used to assess the severity of symptoms of depression and anxiety, respectively $(11,12)$. Each response is assigned a score, ranging from 0 (not at all bothered) to 3 (severely bothered), indicating the severity of the symptoms.

Individual questions of the BDI assess mood, pessimism, sense of failure, self-dissatisfaction, guilt, punishment, selfdislike, self-accusation, suicidal ideas, crying, irritability, social withdrawal, body image, work difficulties, insomnia, fatigue, appetite, weight loss, bodily preoccupation and loss of libido. It was translated into Turkish, and its reliability was recalculated by Hisli (13). For the Turkish population, a score of 17 or above represents depression, according to Hisli (13). We used these cut-off scores to determine the levels of depression.

The BAI is designed to measure anxiety levels. It is scored by summing the responses, with higher total scores indicating higher levels of anxiety. The validity and reliability of the BAI in the Turkish population have been shown by Ulusoy et al. (14).

\section{Sample size}

The sample size of 41 patients per arm provides approximately $80 \%$ power at the two-sided significance level of $5 \%$ to detect at least a twofold increase in the frequency of anxiety and depression in patients with $\mathrm{HG}$, assuming that the incidence of anxiety and depression is $10 \%$ in uncomplicated pregnancies (10).

\section{Statistical analysis}

Statistical analyses were performed using the SPSS for the Windows version 13.0 program. Continuous variables were reported as mean \pm standard deviation (SD). Categorical variables were reported as number and percent. Normality for continuous variables in groups was determined by the Shapiro Wilk test. The variables showed a normal distribution ( $p>0.05)$, so an unpaired t test and a Pearson's chi-square test were used to compare the continuous and categorical variables between the groups. A value of $\mathrm{p}<0.05$ was considered statistically significant.

\section{Results}

Obstetric characteristics of the groups in terms of age, parity, gestational age and weight at admission were similar and are 
shown in Table 1 ( $p>0.05)$. The distribution of educational level and monthly income in the study and control groups is given in Table 2.

There were no statistically significant differences between the groups with respect to the baseline laboratory investigations (Table 3) except the mean serum potassium level, which was significantly lower in patients with HG than in the control group $(\mathrm{p}=0.039)$.

Table 1. Demographic data of the HG and control groups

\begin{tabular}{|l|c|c|c|}
\hline & $\begin{array}{c}\text { HG } \\
(\mathbf{n = 4 1 )}(\mathbf{m e a n} \pm \text { SD) }\end{array}$ & $\begin{array}{c}\text { Control } \\
(\mathbf{n = 4 5 )} \text { (mean } \pm \text { SD) }\end{array}$ & p \\
\hline Maternal age (years) & $27.5 \pm 6.0$ & $29.6 \pm 6.5$ & 0.141 \\
\hline Parity & $1.14 \pm 1.20$ & $1.10 \pm 1.17$ & 0.815 \\
\hline Gestational age (weeks) & $9.5 \pm 2.3$ & $10.5 \pm 2.8$ & 0.07 \\
\hline Pre-preg. weight & $64.5 \pm 9.0$ & $62.4 \pm 10.2$ & 0.336 \\
\hline Pre-preg. BMI & $24.0 \pm 2.4$ & $23.5 \pm 3.4$ & 0.24 \\
\hline Weight at admission & $62.6 \pm 8.3$ & $64.3 \pm 9.3$ & 0.518 \\
\hline BMI at admission & $23.1 \pm 2.4$ & $24.1 \pm 3.2$ & 0.09 \\
\hline
\end{tabular}

Table 2. Distribution of educational level and monthly income of the HG and control groups

\begin{tabular}{|c|c|c|c|c|c|}
\hline \multirow{2}{*}{$\begin{array}{l}\text { Parameter } \\
\text { Education }\end{array}$} & \multicolumn{2}{|c|}{ HG $(n=41)$} & \multicolumn{2}{|c|}{ Control $(n=45)$} & \multirow[t]{2}{*}{$\mathbf{p}$} \\
\hline & $\mathbf{N}$ & $\%$ & $\mathbf{N}$ & $\%$ & \\
\hline Primary-Middle school & 26 & 64 & 22 & 48.9 & \multirow{3}{*}{0.127} \\
\hline High school & 9 & 22 & 19 & 42.2 & \\
\hline College & 6 & 14.6 & 4 & 8.9 & \\
\hline \multicolumn{6}{|l|}{ Monthly income } \\
\hline$* \mathrm{TL}<500$ & 13 & 31.7 & 18 & 40 & \multirow{4}{*}{0.844} \\
\hline *TL 500-1000 & 15 & 36.6 & 13 & 28.9 & \\
\hline *TL 1000-2000 & 8 & 19.5 & 9 & 20 & \\
\hline$* \mathrm{TL}>2000$ & 5 & 12.2 & 5 & 11.1 & \\
\hline * Turkish liras & & & & & \\
\hline
\end{tabular}

Table 3. Laboratory values of the $\mathrm{HG}$ and control groups

\begin{tabular}{|l|c|c|c|}
\hline & $\begin{array}{c}\text { HG } \\
(\mathbf{n = 4 1})\end{array}$ & $\begin{array}{c}\text { Control } \\
(\mathbf{m}=\mathbf{4 5}) \text { (mean } \pm \text { SD) }\end{array}$ & p \\
\hline $\mathrm{Hb}(\mathrm{g} / \mathrm{dl})$ & $12.8 \pm 1.03$ & $15.1 \pm 17.3$ & 0.398 \\
\hline White blood cell $\left(10^{3} / \mathrm{ml}\right)$ & $8.8 \pm 2.4$ & $9.3 \pm 1.9$ & 0.276 \\
\hline Platelet $\left(10^{3} / \mathrm{ml}\right)$ & $241 \pm 49.9$ & $248 \pm 59.2$ & 0.532 \\
\hline $\mathrm{Na}(\mathrm{mmol} / \mathrm{l})$ & $135.2 \pm 2.36$ & $133.9 \pm 18.9$ & 0.661 \\
\hline $\mathrm{K}(\mathrm{mmol} / \mathrm{l})$ & $3.8 \pm 0.39$ & $4.01 \pm 0.48$ & 0.039 \\
\hline ALT $(\mathrm{U} / \mathrm{l})$ & $17.4 \pm 13.6$ & $16.2 \pm 10.9$ & 0.644 \\
\hline AST $(\mathrm{U} / \mathrm{l})$ & $15.9 \pm 8.6$ & $14.2 \pm 4.20$ & 0.254 \\
\hline Urea $(\mathrm{mg} / \mathrm{dl})$ & $8.4 \pm 2.2$ & $8.07 \pm 2.79$ & 0.533 \\
\hline Creatinine $(\mathrm{mg} / \mathrm{dl})$ & $0.67 \pm 0.71$ & $0.54 \pm 0.10$ & 0.228 \\
\hline TSH $(\mu \mathrm{IU} / \mathrm{ml})$ & $1.02 \pm 0.83$ & $1.22 \pm 0.93$ & 0.336 \\
\hline Total hCG $\left.\left(10^{3}\right) \mathrm{IU} / \mathrm{ml}\right)$ & $105 \pm 47.14$ & $89 \pm 42.11$ & 0.107 \\
\hline
\end{tabular}

Mean BDI and BAI scores for the two groups are given in Table 4. Patients with HG had significantly higher BDI and BAI scores than control cases $(p=0.0001$ and $p=0.049$, respectively). Furthermore, $63.4 \%(n=26)$ of the patients in the HG group and $28.8 \%(n=13)$ of the control cases had a BDI score higher than 17 . The difference was statistically significant $(p=0.0001)$.

The mean number of vomiting attacks in the HG group was 5.7, ranging from 1-10 per day. All patients in the study group were 
Table 4. Comparison of BDI and BAI scores of the HG and control groups

\begin{tabular}{|l|c|c|c|}
\hline & $\begin{array}{c}\text { HG } \\
(\mathbf{n}=\mathbf{4 1})(\mathbf{m e a n} \pm \mathbf{S D})\end{array}$ & $\begin{array}{c}\text { Control } \\
(\mathbf{n}=\mathbf{4 5})(\mathbf{m e a n} \pm \mathbf{S D})\end{array}$ & $\mathbf{p}$ \\
\hline BDI & $20.9 \pm 10.4$ & $11.8 \pm 10.24$ & 0.0001 \\
\hline BAI & $18.5 \pm 11.5$ & $13.6 \pm 11.24$ & 0.049 \\
\hline
\end{tabular}

admitted to the inpatient department for the treatment of hyperemesis. The mean length of hospital stay was 1.4 days, ranging from 1-7 days. None of the patients required parenteral nutrition.

\section{Discussion}

This study has shown that women with severe vomiting during their pregnancy had considerably more anxiety and depression than a well-matched control group of healthy antenatal women. Hisli defined the depression limit point in the Beck depression scale as 17 and above for the Turkish population (13). According to this cut-off value, it was determined that more than half of our patients were depressive. This considerably higher level of depression in pregnant patients with HG may be due to inadequate food intake, lack of energy and severe fatigue, lack of socialization, loss of hope that nausea and vomiting will cease before birth and fear of not being able to feed the developing baby.

It is unquestionable that pregnancy itself is a major life stressor that can precipitate or exacerbate depressive tendencies. In a Swedish population-based study, Andersson et al. reported a 14-percent point prevalence of psychiatric disorders during pregnancy $(15,16)$.

Increased stress, depression or anxiety related with pregnancy may be more marked in women suffering from hyperemesis. However, these women are often excluded from studies of the emotions of women during pregnancy, and not enough is known about their psychological state. It is important to recognise and treat maternal anxiety and depression in pregnant patients with hyperemesis, both for the sake of the women themselves and their foetuses. It has been shown that women with prenatal anxiety or stress have higher rates of spontaneous abortion $(17,18)$ and are more likely to deliver premature infants (19). There is also evidence that if a mother is significantly stressed while pregnant, her child is substantially more likely to have emotional or cognitive problems, including an increased risk of attention deficit/hyperactivity disorder, anxiety and language delay (20).

A few previous studies have examined the relationship between anxiety and/or depression and $\mathrm{HG}$, and the results have been inconclusive. Swallow et al. showed that nausea and vomiting in early pregnancy was associated with psychiatric morbidity (21). They reported that the severity of nausea and vomiting correlated independently with the level of anxiety/ insomnia and depression. Similarly, Poursharif et al. showed that in a large cohort of women with $\mathrm{HG}$, over $80 \%$ reported a negative psychosocial impact, including anxiety and depression, some of which continued after the pregnancy (22). In their review, Kim et al. suggested that the quality of life of women with HG is severely disrupted and normalizing the patient's sense of demoralization should always be considered during the treatment of these cases (23). Other studies, however, contradict these findings and found no increase in psychiatric illness in women with HG during pregnancy $(24,25)$. In the present investigation, we also found that mean BDI and BAI scores were significantly higher in hyperemetic pregnant patients than in the control antenatal women $(\mathrm{p}<0.05)$. In the HG group, 26 women (63.4\%) had a BDI score of higher than 17, signifying depression for the Turkish population (13), compared with only $13(28.8 \%)$ of the controls.

It is unclear whether the psychological or psychiatric morbidity is a cause or consequence of HG. In the past, severe vomiting during pregnancy was often perceived as an expression of maternal resentment towards her unwanted pregnancy. Various psychological stresses have been linked with hyperemesis, including emotional immaturity, strong mother dependence and anxiety and tension related to the pregnancy. More recently, however, investigators have argued that the psychological symptoms are a result of stress arising from the physical burden of $\mathrm{HG}$ rather than a cause (21). All the patients in the present study knew they had hyperemesis of pregnancy. Interestingly, Sikkema et al. found anxiety levels to be lower in women with preeclampsia who were unaware of their condition (26).

The present study has clear limitations. The major limitation to this study design was the fact that only a small number of hyperemetic pregnant patients were surveyed and that the results were obtained from a single institution. Other limitations of our study included its subjective nature and data collection method, which created difficulties in ascertaining a 'cause and effect' relationship between the higher anxiety and depression and HG. In conclusion, this study adds to the evidence that those suffering with HG during pregnancy may be more anxious and depressed than women with uncomplicated pregnancies. Depression and anxiety during pregnancy are treatable but can be devastating for maternal and foetal health. Therefore, health professionals need to be aware that extra psychological support may be necessary during the treatment and follow-up of hyperemetic pregnant women.

\section{Conflict of interest}

No conflict of interest was declared by the authors.

\section{References}

1. Eliakim R, Abulafia O, Sherer DM. Hyperemesis gravidarum: a current review. Am J Perinatol 2000; 17: 207-18. [CrossRef]

2. American College of Obstetrics and Gynecology. ACOG (American College of Obstetrics and Gynecology) practice bulletin: Nausea and vomiting of pregnancy. Obstet Gynecol 2004; 103: 803-14.

3. Fishell A. Depression and anxiety in pregnancy. J Popul Ther Clin Pharmacol 2010; 17: 363-9. 
4. Hartley M, Tomlinson M, Greco E, Comulada WS, Stewart J, le Roux I, et al. Depressed mood in pregnancy: Prevalence and correlates in two Cape Town peri-urban settlements. Reprod Health 2011; 8: 9. [CrossRef]

5. Gavin NI, Gaynes BN, Lohr KN, Melzer-Brody S, Gartlehner G, Swinson T. Perinatal depression. Obstet Gynecol 2005; 106: 107183. [CrossRef]

6. Sandven I, Abdelnoor M. Critical appraisal of case-control studies of risk factors or etiology of hyperemesis gravidarum. Arch Gynecol Obstet 2010; 282: 1-10. [CrossRef]

7. Byers BD, Snyder CH, Saade GR. Pregnancy complicated by cyclic vomiting syndrome. Obstet Gynecol 2009; 114: 432-4. [CrossRef]

8. Mazzotta P, Stewart D, Atanackovic G, Koren G, Magee LA Psychosocial morbidity among women with nausea and vomiting of pregnancy: Prevalence and association with anti-emetic therapy. J Psychosom Obstet Gynaecol 2000; 21: 129-36. [CrossRef]

9. Pedersen W. Abortion and depression: A population-based longitudinal study of young women. Scand J Public Health 2008; 36: 424-8. [CrossRef]

10. Tan PC, Vani S, Lim BK, Omar SZ. Anxiety and depression in hyperemesis gravidarum: prevalence, risk factors and correlation with clinical severity. Eur J Obstet Gynecol Reprod Biol 2010; 149: 153-8. [CrossRef]

11. Beck AT. An inventory for measuring depression. Arch Gen Psychiatry 1961; 4: 561-71. [CrossRef]

12. Beck AT, Epstein N, Brown G, Steer RA. An inventory for measuring clinical anxiety: Psychometric properties. J Consult Clin Psychol 1988; 56: 893-7. [CrossRef]

13. Hisli N. Beck depresyon envanterinin geçerliliği üzerine bir çalışma. Psikoloji Dergisi 1988; 22: 118-26.

14. Ulusoy M, Sahin NH, Erkmen H. Turkish version of the Beck Anxiety Inventory: Psychometric properties. J Cogn Psychother 1998; 12: 23-9.

15. Andersson L, Sundström-Poromaa I, Bixo M. Point prevalence of psychiatric disorders during the second trimester of pregnancy: A population-based study. Am J Obstet Gynecol 2003; 189: 148-54. [CrossRef]

16. Vythilingum B. Anxiety disorders in pregnancy. Curr Psychiatry Rep 2008; 10: 331-5. [CrossRef]
17. Sugiura-Ogasawara M, Furukawara TA, Nakano Y, Hori S, Aoki K, Kitamura T. Depression as a potential causal factor in subsequent miscarriage in recurrent spontaneous abortion. Hum Reprod 2002; 17: 2580-4. [CrossRef]

18. Nakano Y, Oshima M, Sugiura-Ogasawara M, Aoki K, Kitamura T, Furukawa TA. Psychosocial predictors of successful delivery after unexplained recurrent spontaneous abortions: A cohort study. Acta Psychiatr Scand 2004; 109: 440-6. [CrossRef]

19. Wadhwa PD, Garite TJ, Porto M, Glynn L, Chicz-DeMet A, DunkelSchetter C, et al. Placental corticotropin-releasing hormone $(\mathrm{CRH})$, spontaneous preterm birth, and foetal growth restriction: A prospective investigation. Am J Obst Gynecol 2004; 191: 1063-9. [CrossRef]

20. Talge NM, Neal C, Glover V. Early stress, translational research and prevention science network: Fetal and neonatal experience on child and adolescent mental health. Antenatal maternal stress and long-term effects on child neurodevelopment: How and why? J Child Psychol Psychiatry 2007; 48: 245-61. [CrossRef]

21. Swallow BL, Lindow SW, Masson EA, Hay DM. Psychological health in early pregnancy: Relationship with nausea and vomiting. J Obstet Gynaecol 2004; 24: 28-32. [CrossRef]

22. Poursharif B, Korst LM, Fejzo MS, MacGibbon KW, Romero R, Goodwin TM. The psychosocial burden of hyperemesis gravidarum. J Perinatol 2008; 28: 176-81. [CrossRef]

23. Kim DR, Connolly KR, Cristancho P, Zappone M, Weinrieb RM. Psychiatric consultation of patients with hyperemesis gravidarum. Arch Womens Ment Health 2009; 12: 61-7. [CrossRef]

24. Tsang IS, Katz VL, Wells SD. Maternal and foetal outcomes in hyperemesis gravidarum. Int J Gynaecol Obstet 1996; 55: 231-5. [CrossRef]

25. Majerus PW, Guze SB, Delong WB, Robins E. Psychologic factors and psychiatric disease in hyperemesis gravidarum: A follow-up study of 69 vomiters and 66 controls. Am J Psychiatry 1960; 117: 421-8.

26. Sikkema JM, Van BB, Franx A, Bruinse HW, de Roos R, Stroes ES et al. Placental superoxide is increased in preeclampsia. Placenta 2001; 22: 304-8. [CrossRef] 